\title{
TOWARD REgulatory MASS REDRESS SCHEMES - MASS REDRESS IN FinanCIAL Mis-SElling SCANDAlS IN THE U.S., THE U.K. AND SOUTH KOREA -
}

\author{
YOU KYUNG HUH*
}

\section{INTRODUCTION}

Collective actions such as class litigation, once hailed as the conventional go-to remedy for mass harm, have proved to be expensive, inefficient, and ineffective. ${ }^{1}$ Alternative dispute resolution systems (ADR), online dispute resolution (ODR) systems, and collective forms of $\mathrm{ADR} / \mathrm{ODR}^{2}$ are increasingly gaining attention as possible solutions to the problems of collective actions. ${ }^{3}$ In some nations, the role of the consumer ombudsman has come to the fore. Regulatory redress schemes, often used in tandem with consumer ombudsmen systems, are the newest redress "technology," and they are the focus of this paper. The term "regulatory redress" refers broadly to a situation where the "intervention of a public authority" ensures recompense for injured consumers. ${ }^{5}$ This regulatory power can include both "soft" influence (where a public authority might be able to persuade, conciliate, or mediate redress) and "hard" enforcement (where a public authority requires a redress scheme).

This paper analyzes case studies from three nations that have recently used regulatory redress schemes to address widespread financial mis-selling scandals. In response to the inappropriate sales of credit card add-on products in the United States, the Consumer Financial Protection Bureau (CFPB) ordered financial companies to repay consumers whom these deceptive practices harmed. ${ }^{6}$ In the United Kingdom, the Financial Conduct Authority (FCA) and the Financial Ombudsman Service (FOS) ordered and managed consumer redress schemes that reimbursed millions of consumers who were mis-sold payment protection insurance (PPI) policies. ${ }^{7}$ In South Korea, the Financial Supervisory Service (FSS) advised financial companies to repay consumers for mis-sold credit card add-on products.

*S.J.D. Candidate at the University of Virginia School of Law; Member of the Korean Bar; Director of Consumers Korea.

1. See generally Christopher Hodges \& StefaAn Voet, Delivering Collective Redress: New Technologies (Hart Publishing, 2018).

2. Some ADR bodies have the capacity to aggregate individual claims and decide them collectively, while others do not. Id. at 2.

3. See Vicki Waye \& Vince Morabito, Collective Forms of Consumer Redress: Financial Ombudsman Service Case Study, 12 J. CoRP. L. STUdiEs 1, 1 (2012).

4. HodGES \& VOET, supra note 1 , at 7.

5. Id. at 153 .

6. See infra Part II. B. (2).

7. See generally Eilis Ferran, Regulatory Lessons from the Payment Protection Insurance Mis-selling Scandal in the U.K., 13 EuR. Bus. OrG. L. REV. 247 (2012). 
The regulatory case studies cited in this article all involve harm to consumers caused by financial products. Regulatory mass redress works exceptionally well in the financial services sector because, unlike any other industry, it is a heavily regulated industry that offers regulators unique opportunities to access information and intervene at an early stage. The wide variety of enforcement mechanisms available to financial regulators creates incentives for the regulated entities to offer redress voluntarily and promptly. Further, as the consumer harm that financial products cause can easily be widespread, inconspicuous, and of low-value in individual cases, policymakers have come to consider regulatory mass redress as an attractive alternative to traditional class action litigation.

Regulatory redress schemes operate in the broader milieu of each nation's unique civil justice system and financial regulatory architecture. In the U.S. and the U.K., financial authorities promulgate, impose, and operate explicit legal mandates, guidelines, and procedures regarding consumer restitution or redress schemes. In contrast, the South Korean case lacks a legal basis for its consumer redress scheme and is much more informal.

What these regulatory redress schemes have in common is that they can be very accessible, effective, and efficient, particularly in low-value but widespread financial mis-selling cases. However, regulatory redress schemes are not without drawbacks. Critics argue that consent replaces the rule of law, and administrative actions replace due process. ${ }^{8}$ They also raise the concern that the new processes emphasize efficiency over the right to a fair trial by an independent judiciary that will consider the evidence and apply the law. ${ }^{9}$ Thus, designing an optimal regulatory redress scheme becomes a balancing act between efficiency gains and due process. This paper reflects on the implications of these three case studies and proposes various factors that legislators should consider when designing regulatory redress schemes.

\section{DELIVERING CONSUMER REDRESS}

\section{A. Pathways to Delivery}

Modern consumer protection policy appropriately places consumers' rights to redress at its center. ${ }^{10}$ Several pathways deliver redress for consumer harm, although some are more effective and efficient than others. This section briefly

8. Micheal Legg, Many Wrongs Can Make a Right: How Mass Redress Schemes Can Replace Court Action (Nov. 23, 2015), http://theconversation.com/many-wrongs-can-make-aright-how-mass-redress-schemes-can-replace-court-action-51118 [https://perma.cc/9MTZ-964].

9. Id.

10. See United Nations Conference on Trade and Development, Dispute Resolution and Redress at 1 (Jul. 9-10, 2018), https://unctad.org/meetings/en/SessionalDocuments/cicplpd11_ en.pdf) [https://perma.cc/Y66Q-MLJM] [hereinafter UNCTAD (2018)]. 
surveys the options available to consumers around the world to deliver redress for harm and examines recent global trends and discussions.

Access to judicial redress is the most common form of recompense available to harmed consumers in most nations. ${ }^{11}$ Legislators modify traditional civil procedures, however, when they seek to redress the imbalance between the consumers and the industry that stem from information and bargaining power asymmetry. ${ }^{12}$ Further, in the consumer and competition area, many cases involve mass injuries, where harm is widespread but individual claims are small. In this situation, it is rational for individual consumers to choose not to litigate because their expected benefits from a court claim do not justify the related costs. ${ }^{13}$

Collective redress has successfully extended the protection of the law to consumers for whom individual civil actions have proven unviable. Collective redress in the form of judicial class litigation is the most well known scheme. ${ }^{14}$ In a class action suit, a group of individuals who have suffered the same or similar loss or harm can resolve their claims (with the same or similar legal or factual issues) against a defendant in a single litigation. Class action mechanisms allow a day in court for low-value individual cases arising from a broad-based consumer harm, which would otherwise not be possible.

Many variations of class action mechanisms exist. The U.S.-style of these is the most well known and the most widely used. ${ }^{15}$ Recently, however, jurisdictions that are in the process of adopting a class action system, or of reforming their existing system, have consciously rejected the litigation-friendly culture of the U.S., and are instead devising mechanisms that suit their own jurisdictions. ${ }^{16}$ For example, when considering the collective redress system for the EU, the EU Commission's 2018 proposal on collective redress sets higher barriers to litigation that typically apply to the U.S. ${ }^{17}$ South Korea, which is currently contemplating class action reform, ${ }^{18}$ has a more limited collective

11. Id. at 6 ("available to all UNCTAD member states" which consists of 195 nations across the world). See Membership of UNCTAD and of the Trade and Development Board, UNCTAD, https://unctad.org/en/Pages/About\%20UNCTAD/UNCTADs-Membership.aspx [https://perma.cc/U2N8-JXC3] (archived Aug. 18, 2019).

12. UNCTAD (2018), supra note 10, at 6.

13. See Christopher Hodges, Current Discussions on Consumer Redress: Collective Redress and ADR, 13 ERA Forum 11, 16 (2012).; UNCTAD (2018), supra note 10, at 6.

14. See Hodges, supra note 13; UNCTAD (2018), supra note 10, at 6.

15. See Hodges, supra note 13, at 11.

16. See, e.g.,, Japan, Korea, and the EU.

17. A New Deal for Consumers: Commission strengthens EU consumer rights and enforcement, EUROPEAN COMMISSION, https://europa.eu/rapid/press-release_IP-18-3041_en.htm [https://perma.cc/MZJ9-4LCW] (archived Oct. 23, 2019). The press release states that the EU model will have "strong safeguards and is distinctly different from US-style class actions." Specifically, the representative action allowed under the new EU system will be open only to eligible non-profit entities like consumer organisations, to avoid "the risk of abusive or unmerited litigation".

18. South Korea, U.S., ChAmber InSTITUTE FOR LEgAL ReFORM, https://www. 
redress system. ${ }^{19}$

Regardless of the specific form (U.S.-style or EU-recommended style), court-led consumer redress has proven to be expensive, inefficient, and ineffective as a remedy for mass harm. ${ }^{20}$ Court proceedings (whether collective or not), present challenges for consumers, including the lengthy duration of the procedures, the associated high costs (especially if the action fails), and the complexity of laws and procedures. ${ }^{21}$ Some commentators even argue that litigation-based actions are "old technologies" compared to some of the newer options that this paper discusses below. ${ }^{22}$

Policymakers have developed alternative dispute resolution (ADR) methods as alternatives to costly litigation. ADR is a way of settling a complaint out of court with the assistance of impartial dispute resolution bodies such as conciliators, mediators, arbitrators, ombudsmen, and complaint boards. ADR is an attractive option for consumer disputes because it is easier, faster, and less expensive than going to court. This option first appeared in the U.S., then spread to other countries, including Canada, Australia, South Korea, and several in Europe. The EU directive on consumer ADR sets forth the quality criteria that it requires $\mathrm{ADR}$ bodies to meet to ensure that they resolve disputes in an effective, fair, independent, and transparent manner. ${ }^{23}$

Another new form of redress is online dispute resolution (ODR). The digital dimension of the market has grown in importance as consumers purchase and transact more online. ODR consists of mechanisms for resolving disputes by

instituteforlegalreform.com/global/south-korea [https://perma.cc/5ENM-E9UE] (archived Oct. 23, 2019).

19. Class action for general claims are not available in Korea. Only securities-related damages are recoverable by class actions under the Securities-Related Class Action Act. For a general overview of class action in Korea see Class/collective actions in South Korea: overview, Kim \& Chang, https://uk.practicallaw.thomsonreuters.com/5-617-3110?transitionType= Default\&contextData $=($ sc. Default $) \&$ firstPage $=$ true \&bhcp $=1 \quad$ [https://perma.cc/BUW8-F3TC]. For a comprehensive comparison of the Korean securities class action rules and the U.S. rules, see generally Benjamin Joon-Buhm Lee, Saving the Korean Securities Class Action, 39 U. PA. J. INT'L L. 247 (2017), https://scholarship.law.upenn.edu/jil/vol39/iss1/6 [https://perma.cc/TS89435L].

20. See Hodges, supra note 13, at 18; See generally Hodges \& VoET, supra note 1.

21. UNCTAD (2018), supra note 10, at 6. Alexander Biard, Collective Redress in the EU: A Rainbow Behind the Clouds?, 18 ERA FoRUM 189, 195 (2018), https://doi.org/10.1007/s12027018-0509-4 [https://perma.cc/3DX2-6JEJ] (citing an evaluation report of the EU, "in practice affected persons do not use them due to the rigid conditions sent out in national legislation, the lengthy nature of procedures or perceived excessive costs in relation to the expected benefits of the actions.").

22. See generally Christopher Hodges, Collective Redress: The Need for New Technologies, 42 J. CONSUMER POL'y REv. 59 (2018) [hereinafter Collective Redress].

23. European Parliament, Directive 2013/11/EU of the European Parliament and of the Council of 21 May 2013 on Alternative Dispute Resolution for Consumer Disputes and Amending Regulation (EC) No. 2006/2004 and Directive 2009/22/EC (June 18, 2013), https://eurlex.europa.eu/legal-content/EN/TXT/?uri=celex\%3A32013L0011 [https://perma.cc/L9SC-B2W. 
using electronic communication. ${ }^{24}$ It can offer simple, efficient, fast, and lowcost out-of-court solutions. ${ }^{25}$ Major online platforms like eBay and Paypal were the first to develop ODR. ${ }^{26}$ ODR platforms can manage significantly more complaints than can any court system. ${ }^{27}$ Emulating these private ODR systems, more countries are adopting ODR, or at least some of its elements, as part of their public redress mechanisms. ${ }^{28}$ For example, in accordance with the 2018 EU directive, the European Commission operates an online dispute resolution site through which any consumer who bought goods or services online from an EU trader can file a complaint. ${ }^{29}$

One final option for consumer redress is the ombudsman. Operating in a number of nations, consumer ombudsman schemes offer a type of specialized ADR system that provides some form of redress; can systematically assess individual issues to analyze complaint patterns; and draw broader implications on a specific product or industry. ${ }^{30}$

Consumer ombudsman work in cooperation with regulators. They can formulate recommendations in light of their systemic analysis, inform legislation or rule changes, and give feedback to traders. ${ }^{31}$ While some consumer ombudsmen provide general services for overall consumer complaints, such schemes generally work best in specialized areas, such as the financial services, communications, or energy sectors. ${ }^{32}$ The most significant benefit of ombudsmen is their ability to provide collective redress. Although both ADR and ODR have their advantages, they are limited as mechanisms for collective consumer redress because traditionally, they provide only individual redress for consumers, ${ }^{33}$ and individual redress is still an inefficient way to resolve mass harm. Consumer ombudsman schemes that work in tandem with regulatory authorities and allow regulatory mass redress, thus, offer a promising solution for mass consumer harm.

24. PABlo Cortés, ONLINE Dispute Resolution FOR CONSUMERS IN THE EUROPEAN UNiON 85 (Routledge, 2011) (Note. 1 states, "ODR is understood as any method used to settle disputes that are conducted mainly through the use of ICT (i.e., automated negotiation, assisted negotiation, online mediation, online arbitration, cybercourts, etc.).

25. European Parliament, supra note 23.

26. UNCTAD (2018), supra note 10, at 9.

27. $I d$.

28. Some ODR practices have elements of the dispute resolution carried out offline (e.g., in South Korea) an ODR scheme managed by the Korean IT Industry Promotion Agency incorporates offline (e.g., face-to-face method). See Okkyeong Bang, Current Practices of ODR in Korea (Sept. 21, 2012), http://uncitralrcap.org/wp-content/uploads/2015/11/Day2_Panel1_2_ Okkyeong-Bang_Current-Practices-of-ODR-in-KOREA.pdf [https://perma.cc/8JYC-EV5X].

29. European Parliament, supra note 23.

30. See Hodges \& VoEt, supra note 1 at 212; see Waye \& Morabito, supra note 3.

31. See Hodges \& VoET, supra note 1.

32. Id.

33. Collective Redress, supra note 22, at 67. 
[Vol. 30:99

\section{B. Regulatory Mass Redress}

This paper uses the term "regulatory redress" to refer broadly to a generic term of the redress made that consumers receive through the "intervention of an administrative authority." ${ }^{\prime 34}$ As noted in the previous sections, courts are not the only institutions in which consumers rely on redress. ADR, ODR, and ombudsman schemes provide alternatives to court remedies. As the following case studies will show, more examples are emerging in which the public authorities that enforce consumer protection laws are shifting their attention to restitution for wronged consumers rather than just focusing on the deterrence of wrongdoing. ${ }^{35}$ In addition, the UN Guidelines on Consumer Protection also offer administrative options for consumer redress. ${ }^{36}$

Administrative authorities with investigative, regulatory, supervisory, or enforcement powers regarding consumer laws or specific industries can intervene to require traders to recompense harmed consumers. ${ }^{37}$ One example of such an administrative authority is the public official responsible for consumer law enforcement, such as the Consumer Ombudsman in Nordic countries: Denmark, Finland, Norway, and Sweden. ${ }^{38}$ In these nations, the administrative authority can bring a case to the court to seek collective redress. ${ }^{39}$ Other nations have sector-based administrative authorities that can intervene to seek consumer redress. The financial regulators who hold this role appear in this paper's case studies.

This paper deliberately uses "intervention" in its broadest sense to encompass the variety of redress schemes that exist globally. Borrowing from the typology of Christopher Hodges \& Stefaan Voet in Delivering Collective Redress: New Technology regulatory power includes "soft" influence approval - and "hard" influence - coercion. ${ }^{40}$ Soft influence exists where a public authority might be able to persuade, conciliate, or mediate redress. ${ }^{41}$ This public authority might have formal enforcement powers that indirectly influence the payer to rectify the harm that it has caused. ${ }^{42}$ Making voluntary redress could

34. Hodges \& VoeT, supra note 1, at 153 uses the phrase "intervention of a public authority" in defining regulatory redress (emphasis added). To differentiate from courts, this paper intentionally uses the term "administrative authority" as a way to clarify the exclusion of in-court remedies from the term of "mass regulatory redress."

35. The case studies on the U.S., the U.K., and South Korea set forth in this paper exemplifies this phenomenon. See Hodges \& VoET, supra note 1, at 153-210.

36. As per the United Nations Guidelines for Consumer Protection, which provide: Governments should establish or maintain legal and/or administrative measures to enable consumers or, as appropriate, relevant organizations to obtain redress through formal or informal procedures that are expeditious, fair, inexpensive, and accessible.

37. HoDGES \& VOET, supra note 1 , at 153.

38. Id. at 160 .

39. Id. at 153.

40. Id. at 154. (As seen below, this would be the case for most financial authorities).

41. Id.

42. Id. 
potentially reduce the likelihood and magnitude of a formal enforcement action or criminal penalty against the perpetrator. ${ }^{43}$

The second type of regulatory intervention can come in the form of the approval of a public authority or the court. The U.K. Financial Conduct Authority's approval for a redress scheme is an example of this kind of intervention. ${ }^{44}$ A public authority-approved scheme has the particular advantage of ensuring autonomy, flexibility, and speed, while also scrutinizing the fairness of the redress terms. ${ }^{45}$ Settlement or an agreement between the regulated entity and the public authority on consumer redress also falls under the "approval" category of regulatory intervention.

Finally, the third type of regulatory intervention is "hard" enforcement or "coercion," where a public authority requires a redress scheme. An obvious case would be where the authority orders a person or a company to compensate the injured party. ${ }^{46}$ One example of this is the FCA's power to compel firms to initiate and administer mandatory consumer redress schemes under s404 of the Financial Services and Market Act (FSMA). Another example is the Consumer Ombudsman of Denmark's ability to initiate a class action on behalf of consumers. ${ }^{47}$

As the case studies below will demonstrate, in real world cases the typology is not always clear; sometimes regulators employ several mechanisms at the same time. Nonetheless, distinguishing the range of options available to the relevant authorities enhances the understanding and allows comparative evaluation of the different redress mechanisms used in different nations.

\section{CASE STUDIES: RECENT REGULATORY MASS REDRESS SCHEMES}

\section{A. The United Kingdom}

The U.K. has seen an increasing preference for alternative means of collective redress instead of litigation. The country has instituted a robust regulatory redress scheme, which proved its worth in the case of mis-sold PPI insurance. This scandal was the largest in the nation's history. Since 2011, people who complained about mis-sold PPIs have received about $£ 34$ billion in recompense. ${ }^{48}$ The FCA set August 19, 2019, as the deadline for complaints ${ }^{49}$ which has passed at the time of this writing, however, the FCA has yet to publish

43. HoDGES \& VOET, supra note 1 , at 154 .

44. Id. at 155 .

45. Id. at 156 .

46. Id. at 157 .

47. Id.

48. Monthly PPI refunds and compensation, FinAnCial Conduct Authority, https://www.fca.org.uk/data/monthly-ppi-refunds-and-compensation [https://perma.cc/F5HTXLTM] (archived Aug. 18, 2019).

49. Id. 
the final report that will provide a definitive review of the overall impact of FCA's measures and draw the PPI issue to a close.

\section{(1) Mis-selling of Payment Protection Insurance (PPI)}

As far back as the 1970s, but mostly between 1990 and 2010, banks, lenders, and various providers sold as many as 64 million payment protection insurance (PPI) policies to British consumers. ${ }^{50}$ The sellers bundled PPI with credit products such as loans (personal loans, business loans, and student loans), credit cards, store cards, catalogue credit, overdrafts and mortgages, loan secured on homes in addition to the mortgage, home improvement loans (such as for remodeling, furniture, car financing or something bought on credit, such as a sofa - this may have been called a "finance agreement" or "hire purchase."). ${ }^{51}$ Sometimes a PPI came as a standalone product, unrelated to a specific type of credit. ${ }^{52}$ The sellers marketed PPI under different names, such as "accident, sickness and unemployment (ASU) insurance," "account cover," "credit insurance," "credit protection," "loan care," "loan insurance," "loan protection," "loan repayment insurance," "mortgage payment protection insurance (MPPI)," "payment cover," and "protection plan." 53

PPI was mis-sold in the following ways. Sometimes the seller used preticked boxes, in policy agreements so the customer did not know he or she was purchasing PPI ${ }^{54}$ some customers thought the PPI was compulsory- they thought that they could not get credit unless they purchased PPI with their loans; ${ }^{55}$ in some cases, the sellers did not properly explain the terms and conditions of PPI ${ }^{56}$ the commission associated with the PPI and included in its cost was unfair. ${ }^{57}$ Sometimes PPI policies were unnecessary or unsuitable for the consumer because the consumer was ineligible to claim the benefits payable under the policy or was unlikely to need the protection. ${ }^{58}$

50. Payment Protection Insurance Explained, Financial Conduct Authority, (Apr. 29, 2019) https://www.fca.org.uk/ppi/ppi-explained [https://perma.cc/7EPR-CNPQ]; See also NAtional Audit OfFiCe, Financial Services Mis-selling: Regulation and Redress, HC Paper No. 851 (2016).

51. Financial CONDUCT Authority, supra note 50.

52. What is PPI and Did I Have it?, Financial Ombudsman Service, https://www.financial-ombudsman.org.uk/businesses/complaints-deal/ppi/ppi [https://perma.cc/A3XG-9P8H].

53. How to Check if You Had PPI, Financial Conduct Authority (Aug. 7, 2019), https://www.fca.org.uk/ppi/how-to-check [https://perma.cc/W662-F5HX ].

54. Top Five Mis-selling Tactics, WHICH?, https://www.which.co.uk/news/2011/05/topfive-ppi-mis-selling-tactics-253105/ [https://perma.cc/DZ3A-74LZ].

55. Id.

56. Id. For example, the customers were sold PPI even when they had pre-existing medical conditions which was a standard exclusion under many insurance policies.

57. PPI, FinANCIAL OMBUDSMAN SERVICE, https://www.financial-ombudsman.org. uk/ppi/ what-is-ppi.html [https://perma.cc/7D7K-H7MV.

58. Id. 
The combined effect of the long duration of the PPI sales period, the length of time since the products were sold (i.e., decades in some cases), the variety of PPI-related products and sales channels, the variations of how PPI was branded (named), and the unclear, even abusive nature of many of PPI sales was detrimental to the purchasers. Consumers were often unaware of their coverage or unsure whether they had PPI, and lacked the relevant paperwork or statements to check on their status. ${ }^{59}$ This created a significant obstacle for mass consumer redress, eventually forcing the FCA to lead a proactive large-scale communications campaign that involved advertising, PR, social media, and partners. ${ }^{60}$

\section{(2) Regulator's Response and Consumer Redress}

The magnitude and duration of PPI mis-selling was substantial. The U.K. financial authorities' efforts to manage the intervention, which spans over two decades, continue to evolve. Overall, the now-defunct Financial Services Authority ("FSA") and its successor, the FCA, have combined supervisory and regulatory tools ${ }^{61}$ and formal enforcement actions (i.e., fines), with a system of regulatory redress for consumers.

The FSA, which regulated financial services until April 2013, took up the mis-selling of PPI as soon as it assumed oversight of the insurance business in 2005. In that first year, the FSA immediately conducted a thematic review of PPI sales practices, ${ }^{62}$ and in 2009 it banned firms from selling single premium PPIs. ${ }^{63}$ From 2006 to 2010 the FSA imposed 24 enforcement actions against the mis-selling of PPI, with fines totaling $£ 12.6$ million. ${ }^{64}$

Working in cooperation with the FSA/FCA, the Financial Ombudsman Service ("FOS") sought to resolve individual complaints between consumers and businesses. In principle, consumers first had to complain to the financial services firms. Those dissatisfied with the response could then bring the case to

59. Financial Conduct Authority, Policy Statement PS 17/3: Payment Protection Insurance Complaints: Feedback on CP16/20 and Final Rules and Guidance 23 (2017), https://www.fca.org.uk/publication/policy/ps17-03.pdf [https://perma.cc/R5ZQ-CZCU].

60. See Payment Protection Insurance Complaints Deadline Progress Report, FinANCIAL CONDUCT AuthORITY (Oct. 2018), https://www.fca.org.uk/publication/corporate/ppi-complaintsdeadline-progress-report.pdf [https://perma.cc/P6A8-A3UF].

61. See Ferran, supra note 7, at 256.

62. Id. at 255 (citing FSA, The Sale of Payment Protection Insurance: Results of Thematic Work (November 2005); FSA, The Sale of Payment Protection Insurance: Mystery Shopping Results (November 2005)).

63. Id. at 254 (citing FSA, Update on FSA Work on the Sale of PPI, (FSA/PN/012/2009, 20 January 2009); FSA, FSA Wants All firms to Stop Selling Single Premium PPI (FSA/PN/031/2009, 24 February 2009)); FinANCIAL OMbudSMAn SERVICE, supra note 52.

64. Id. at 260 (citing FSA, The Assessment and Redress of Payment Protection Insurance Complaints (PS10/12), at 4)); see also Clydesdale Bank Fined £20,678,300 for Serious Failings in PPI Complaint Handling, Financial Conduct Authority (Apr. 14, 2015), https://www.fca.org.uk/news/press-releases/clydesdale-bank-fined-\%C2\%A320678300-seriousfailings-ppi-complaint-handling [https://perma.cc/F33R-D27R]. 
the FOS.$^{65}$ The number of complaints concerning payment protection insurance that consumers filed with the "FOS jumped from 1,315 in 2006 to 104,597" in $2011,{ }^{66}$ and continued to increase massively after that, with 400,000 new PPI claims filed in both 2012-13 and 2013-14. ${ }^{67}$ This upsurge in complaints presented a major challenge to the FOS and significantly strained its resources, as it found it necessary almost to triple in size as it took on new case handlers and adjudicators. ${ }^{68}$

The number of PPI complaints piling up at the FOS and the FOS's referral to the FSA to investigate the wider implications of the complaints compelled the FSA to take a systemic approach to the problem. Accordingly, the FSA created increasingly specific regulations and adopted a focused supervisory regime to handle the complaints. ${ }^{69}$ In 2010, this resulted in "Policy Statement 10/12" - the FSA's announcement of the structure by which it would handle PPI complaints more fairly and consistently, and reduce the FOS's heavy caseload. ${ }^{70}$ Among other things, Policy Statement 10/12 amends the Complaints Sourcebook ("DISP"), the FSA's earlier set of relevant rules. The revised sections include explanations of how firms should handle and assess PPI complaints and how they should deal with evidence and redress regarding these sales. ${ }^{71}$ Policy Statement 10/12 also presented the way in which the FSA planned to monitor firms' behavior regarding PPI complaints, requiring the firms to provide it with sample files of PPI complaints, governance structures, internal procedures, papers, and minutes of senior management meetings about PPI. ${ }^{72}$

Encouraging consumers to file PPI claims was an important aspect of the FSA/FCA's approach to the PPI scandal. In 2012, the FSA issued guidance on how companies should contact consumers so as to facilitate PPI claims. ${ }^{73}$ In 2013, the FCA, published empirical field research about ways to encourage consumers to seek redress. ${ }^{74}$ That paper recommended small changes like adding a message to 'act quickly' to a plain envelope, using an FSA logo in the letterhead; using salient bullets; simplifying the body of the letter; and including in the text an explanation that the claims process would only take five minutes.

65. NATiOnal Audit OfFice, supra note 50, at 36.

66. See Ferran, supra note 7 at 255 (citing Financial Ombudsman Service, Annual Review 2010/11, at 41).

67. NATiOnAL Audit OfFice, supra note 50, at 10.

68. See id.

69. See Ferran, supra note 7, at 263.

70. Financial Services Authority, Policy Statement 10/12: The Assessment and Redress of Payment Protection Insurance Complaints (2010) [hereinafter Policy Statement 10/12].

71. Id. at Appendix 1 Final Handbook text.

72. Id. at 58 .

73. Financial Services Authority, Finalized Guidance, Payment Protection Insurance Customer Contact Letters (PPI CCLs) - Fairness, Clarity and Potential Consequences (2012).

74. Paul Adams \& Stefan Hunt, Encouraging Consumers to Claim Redress: Evidence from a Field Trial, FCA OCCASIONAL PAPERS (Apr. 2013). 
These served to increase the consumer response rate. ${ }^{75}$

To ensure robust and consistent consumer redress, the FSA/FCA's supervisory work also included a program of oversight and review of the progress of consumer redress. The authorities kept track of the monthly and annual number of complaints to firms, the complaint uphold rates, and the amount of PPI redress paid by month and years. ${ }^{76}$ It asked firms to conduct selfassessments, to review complaint handling failures, and to provide the resulting information to the authorities. It also required them to hold regular meetings with the FCA. ${ }^{77}$

In 2017, the FCA issued "Policy Statement 17/3," which, among other matters, set August 29, 2019 as the deadline by which consumers must file their PPI complaints or lose their rights to have them assessed; presented its communications campaign to inform the consumers of this deadline; and imposed the requirement that the financial industry fund the consumer communications campaign. ${ }^{78}$ In accordance with Policy Statement 17/3, the FCA launched a media campaign that has led millions of additional consumers to seek redress. ${ }^{79}$

\section{(3) Implications}

Commentators have hailed the U.K. financial sector's regulatory redress scheme as a very successful system, especially compared to court-led civil justice systems. ${ }^{80}$ They describe the exercise as an "integrated voluntary,

75. Id. See also Becky Rowe, Jenny Holland, \& Ruby Wootton, Financial Conduct Authority: Understanding PPI Redress from a Consumer Perspective, FinANCIAL ConduCT AUTHORITY (Nov. 2015) https://www.fca.org.uk/publication/consultation/understanding-ppiredress-consumer-perspective.pdf. [https://perma.cc/8V4E-9ERH]. The FCA also commissioned behavioral research to understand the mindsets of complaining and non-complaining consumers, and ways to encourage people to complain.

76. Financial Conduct Authority, Thematic Review, Redress for Payment Protection Insurance (PPI) Mis-sales Update on Progress and Looking Ahead, TR 14/14 (2014).

77. Id. at $15-17$.

78. FinANCIAL CONDUCt Authority, supra note 59.

79. Financial Conduct Authority, Payment Protection Insurance Complaints Deadline Progress Report 6 (2018), https://www.fca.org.uk/publication/corporate/ppi-complaintsdeadline-progress-report.pdf [https://perma.cc/CZD5-EL22]. (According to the FCA, during the first ten months of its campaign, it received 8.4 million inquiries, an increase of $40 \%$ monthly compared their immediate pre-campaign level, while consumers made 3.7 million complaints, $63 \%$ more than in the 10 months before the campaign) (One can view an example of a media campaign, featuring a robotic head of Arnold Schwarzenegger, on Youtube at https://www.youtube.com/watch?v=zS9wMHXZ4Ts [https://perma.cc/ULB8-CG2A], or https://www.youtube.com/watch?v=cfwk0bAAfPk [https://perma.cc/959Q-V6CQ]).

80. HodGES \& VOET, supra note 1, at 248; Rebecca Money-Kyrle, Collective Enforcement of Consumer Rights in the United Kingdom (March 01, 2015) (referencing 'IM NAMEN DES

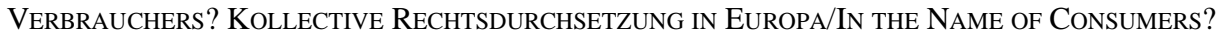
Collective Rights Enforcement in Europe', Schmidt-Kessel M, StrünCK C and Kramme M (EDS), JVW Publishing (2015), https://ssrn.com/abstract=2661980 [https://perma.cc/CT8R- 
regulatory, and Ombudsman redress," and notes that "various techniques can be integrated into a holistic practical approach." 81 The system makes both voluntary redress and regulatory redress available to consumers. The redress could be considered "voluntary" 82 in a sense that it first asked consumers to file a complaint with the firms (rather than the FOS) ${ }^{83}$ Also, in an early stage of the PPI scandal, the firms "voluntarily" repaid the consumers, even before the FSA set guidelines and rules. ${ }^{84}$ The plan could also be considered as a "regulatory" redress because in both 2010 and 2017 the FSA/FCA amended its Handbook (by way of Policy Statements 10/12 and 17/3) and set rules and guidelines for firms to follow. ${ }^{85}$ Along with this, the FOS, addressed individual claims and set the redress standards for them. ${ }^{86}$

It is worth noting that a collective action litigation might have been unfeasible or very ineffective and costly in this situation, because authorities would have had to review each "mis-selling" case individually in light of its specific circumstances; for example, some consumers were more informed than others, and some actually needed the PPI while others did not. ${ }^{87}$ It would have been difficult to put the vast variety of products and sales channels involved into one "class." 88 As such, there was no evidence of any attempt to establish a consumer class (aggregated) litigation, nor of Parliamentary, consumer, or other policy calls to propose such class action-related solution. ${ }^{89}$

\section{B. The United States}

In the United States, the Consumer Financial Protection Bureau ("CFPB")

Y3DG], (commenting, "[w]hilst general criminal and civil justice mechanisms currently in force have failed to deliver, there are other administrative and regulatory routes that provide avenues to collective enforcement of consumer rights in the UK")).

81. HODGES \& VOET , supra note 1, at 252.

82. HODGES \& VOET , supra note 1 , at 254.

83. See NATIONAL Audit OfFice, supra note 50, at 10,

84. See Hodges \& Voet, supra note 1, at 254.

85. See HODGES \& VOET, supra note 1, at 254-56.

86. Richard Thomas, The impact of PPI mis-selling on the Financial Ombudsman Service, 24-25 (2016), https://www.financial-ombudsman.org.uk/files/17749/Impact-of-PPI-mis-sellingreport.pdf [https://perma.cc/V6X9-QCPS].

87. Emma Ann Hughes, FCA Hits Back at Claims it Overwhelmed FOS, FY ADVISOR (Sept. 18, 2018), https://www.ftadviser.com/regulation/2018/09/11/fca-hits-back-at-claims-itoverwhelmed-fos/ [https://perma.cc/84LU-T5X7] (the FCA stated that, "In many instances the nature of the (PPI) complaint is quite specific to the individual.").

88. See Thomas, supra note 86 , at 6 (discussing the FOS's handling of complaints, "[G]iven in particular the complexities of PPI complaints, there would have been significant risks from excessive standardisation in terms of unacceptable quality, inconsistency and poor customer service. ... [A]ny wholesale attempt to group cases any further into cohorts has not been, and is unlikely to be, a viable option.")

89. HODGES \& VOET, supra note 1, at 257. 
charged several banks with "deceptive acts or practices" in connection with their marketing of credit card add-on products. ${ }^{90}$ The CFPB, which Congress created as a response to the Global Financial Crisis of 2008, issued several enforcement actions ordering consumer redress for such deceptive selling. Since the very beginning of the CFPB's operations, it has embraced its role as a financial cop, even describing itself as a "cop on the beat." ${ }^{91}$ As such, consumer redress (i.e., restitution or consumer refund) has been an important component of the CFPB's enforcement actions, as it required the banks in question to refund billions of customers' money. ${ }^{92}$

\section{(1) Misconduct Related to Credit Card Add-on Product Sales}

Credit card add-on products are additional, optional services that credit card companies provide. ${ }^{93}$ Banks or bank-authorized third-party vendors sold "credit protection" or "identity monitoring" as additions to a customer's account. ${ }^{94}$ There was a wide variety of these products, with a diverse scope and design. Just to give one example, between 2010 and 2012, Bank of America marketed credit card payment protection products that allowed customers to request that the bank cancel some amount of credit card debt in the event of certain hardships, like involuntary unemployment or disability, and certain life events, such as entering college or retirement. ${ }^{95}$ This optional coverage required a monthly or annual membership fee but the bank did not always present this

90. Steven Forry, 2012: The CFPB Set Its Sights on Credit Card Companies, AMERICAN BAR AsSOCIATION (2013), https://www.americanbar.org/groups/business_law/publications/blt/ 2013/03/02_forry/ [https://perma.cc/3DQQ-WT3Z]; see also Consent Order, In re Bank of America,; and FIA Card Services, N.A. (No. 2014-CFPB-0004) (Apr. 9, 2014) [hereinafter Bank of America Consent Order], https://files.consumerfinance.gov/f/201404_cfpb_bankofamerica_ consent-order.pdf [https://perma.cc/5XDN-7HQM]; Consent Order, In re First National Bank of Omaha (No, 2016-CFPB-0014) (Aug. 25, 2016), [hereinafter First National Bank Consent Order], https://files.consumerfinance.gov/f/documents/082016_cfpb_FNBOconsentorder.pdf [https:// perma.cc/7GL6-MNGH]; Consent Order, In re Capital One Bank, (USA), N.A. No. (2012-CFPB0001) (Jul, 18, 2012), [hereinafter Capital One Bank Consent Order], https://files. consumerfinance.gov/f/201207_cfpb_consent_order_0001.pdf [https://perma.cc/5F5M-V6XK].

91. Kevin M. McDonald, Who's Policing The Financial Cop on The Beat - A Call for Judicial Review of The Consumer Financial Protection Bureau's Non-Legislative Rules, 35 REV. BANKING \& Fin. L. 225, 227 (2015).

92. See Christopher L. Peterson, Consumer Financial Protection Bureau Law Enforcement: An Empirical Review, 90 Tul. L. Rev. 1057 (2016).

93. See What are Credit Card "Add-On" Products?, Consumer Financial Protection BuREAU (Aug. 8, 2016), https://www.consumerfinance.gov/ask-cfpb/what-are-credit-card-addon-products-en-1541/ [https://perma.cc/L58D-S2E9].

94. Id. See also Bank of America Consent Order, supra note 90, at 6-10.

95. See CFPB Orders Bank of America to Pay \$727 Million in Consumer Relief for Illegal Credit Card Practices, Consumer Financial Protection Bureau (Apr. 9, 2014), https://www.consumerfinance.gov/about-us/newsroom/cfpb-orders-bank-of-america-to-pay727-million-in-consumer-relief-for-illegal-credit-card-practices/ [https://perma.cc/83PV-9SUN]. 
clearly to its customers, and engaged in deceptive practices that I describe below in detail. ${ }^{96}$

CFPB's supervisory oversight discovered that some banks were engaging in high-pressure, confusing, and deceptive promotional practices when marketing the products, including the inadequate disclosure of important terms and conditions. ${ }^{97}$ Some of them enrolled consumers in programs, and even billed them, without the customers' affirmative knowledge or consent. ${ }^{98}$ In some cases, a bank would bill consumers for services that it had not performed or activated. ${ }^{99}$ CFPB's consumer complaint database associated these deceptive marketing and sales practices with credit card add-on products..$^{100}$

Some of the sales methods involved soliciting via telemarketing. For example, in the Bank of America case, the bank's Call Center Representatives ("CSRs") solicited the cardholders who called the bank to activate their cards, encouraging them to enroll in the add-on products. ${ }^{101}$ Bank of America misled some consumers about the enrollment process for these products, telling them that there were additional steps necessary in order to enroll, while in reality, it was registering these consumers in the add-on products during these calls, and charging the unsuspecting customers for them. ${ }^{102}$

\section{(2) Regulator's Response and Consumer Redress}

One of the CFPB's first enforcement actions, in 2012, was against the deceptive selling of credit card add-on products. ${ }^{103}$ The action stemmed from an examination that identified the deceptive marketing tactics of Capital One Bank (U.S.A.), N.A.'s vendors, who pressured or mislead consumers into paying for "add-on products" such as payment protection and credit monitoring when they

96. Consumer Financial Protection Bureau, supra note 93.

97. Bulletin Re: Marketing of Credit Card Add-on Products, CFPB Bulletin 2012-06, Consumer Financial Protection Bureau, (Jul. 18. 2012), [hereinafter CFPB Bulletin], https://files.consumerfinance.gov/f/201207_cfpb_bulletin_marketing_of_credit_card_addon_pro ducts.pdf [https://perma.cc/EU8A-JDGU]. See also Consumer FinANCIAL Protection BurEAU, supra note 94; Bank of America Consent Order, supra note 90, at 7-8; Capital One Bank Consent Order, supra note 90, at 4-7; First National Bank Consent Order, supra note 90, at 7-8; 90 , at 6 .

98. CFPB Bulletin, supra note 97. See also Capital One Bank Consent Order, supra note

99. CFPB Bulletin, supra note 97.

100. Id.

101. Bank of America Consent Order, supra note 90, at 7.

102. Id. See also Consumer Financial Protection Bureau, supra note 95.

103. See CFPB Probe into Capital One Credit Card Marketing Results in $\$ 140$ Million Consumer Refund, Consumer Financial Protection Bureau (July 18, 2012), https://www.consumerfinance.gov/about-us/newsroom/cfpb-capital-one-probe/ [https://perma.cc/VRZ2-QQSP]. 
activated their credit cards. ${ }^{104}$ In this action, the CFPB ordered Capital One to refund approximately $\$ 140$ million to two million customers and to pay an additional \$25 million penalty to the CFPB's Civil Penalty Fund. ${ }^{105}$ The CFPB grounded its enforcement actions on Sections 1053 and 1055 of the Consumer Financial Protection Act of 2010 (CFPA). ${ }^{106}$

Together with this first enforcement action, the CFPB also exercised its supervisory powers by issuing CFPB Bulletin 2012-16, "Marketing of Credit Card Add-on Products." 107 The Bulletin, outlines the CFPB's expectations for institutions under its supervision and their service providers to offer credit card add-on products in compliance with Federal consumer financial law. ${ }^{108}$ The CFPB presents guidelines regarding marketing materials, employee incentive or compensation programs, and scripts and manuals related to credit card add-on products. ${ }^{109}$ In addition, the Bulletin stipulates that "institutions that offer credit card add-on products should employ compliance management programs" $" 110$ that include certain items that are intended to provide guidance for financial companies to follow. ${ }^{111}$

After the initial enforcement action against Capital One Bank, the CFPB issued a series of subsequent actions ordering financial companies to repay consumers for deceptive marketing. ${ }^{112}$ In 2013, it required American Express to refund an estimated $\$ 59.5$ million to more than 335,000 consumers because of deceptive marketing concerning credit card add-on products. ${ }^{113}$ In 2015 , Citibank paid $\$ 700$ million to about seven million consumers in relief for illegal credit card practices related to credit card add-on products and services. ${ }^{114}$ In

104. Id.

105. Id.

106. 12 U.S.C. $\S 5563$ and 5565. See also Capital One Bank Consent Order, supra note 90 , at 1 .

107. CFPB Bulletin, supra note 97.

108. See id.

109. See id.

110. Id. at 5 .

111. See id. However, some commentators have criticized the CPFB's use of bulletins, stating: "The practice of publishing bulletins that officially do not have the effect of law, but nonetheless are otherwise relied upon in enforcement proceedings, contributes to a perception that agencies intentionally bypass the notice-and-comment requirements required for rulemaking through backdoor measures, that is, by issuing guidance documents." McDonald, supra note 91, at 243 .

112. Consumer Financial Protection Bureau: Enforcing Federal Consumer Protection Laws (2016), CONSUMER FinANCIAL Protection Bureau, https://files.consumerfinance. gov/f/documents/07132016_cfpb_SEFL_anniversary_factsheet.pdf [https://perma.cc/BG3AXYLU] (archived Sept. 17, 2019).

113. See CFPB Orders American Express to Pay \$59.5 Million for Illegal Credit Card Practices, Consumer Financial Protection Bureau (Dec. 23, 2016), https://www.consumerfinance.gov/about-us/newsroom/cfpb-orders-american-express-to-pay-595-million-for-illegal-credit-card-practices/ [https://perma.cc/T45U-NRW4].

114. See CFPB Orders Citibank to Pay $\$ 700$ Million in Consumer Relief for Illegal Credit Card Practices, Consumer Financial Protection Bureau, (July 21, 2018), https://www. 
2016, Bank of America had to provide $\$ 727$ million consumers with refunds for deceptive marketing related to credit card add-on products. ${ }^{115}$

What is important about this series of consumer redress actions is the CFPB's dedication to making it easy for consumers to receive relief. Its consent orders usually included very detailed terms about how the consumers should receive redress. The orders laid out the terms of a "Redress Plan" 116 or "Remediation Plan." "117 It required the redress plan to include the following: 1) Convenient repayments to consumers - if the consumers were still customers of the relevant bank, they would receive a credit to their accounts, and if they were no longer bank credit card holders, they would receive a check in the mail. ${ }^{118}$ The CFPB did not require consumers to take any action to receive their repayment. ${ }^{119}$ 2) Calculation methods for restitution or monetary relief. ${ }^{120}$ 3) Requirements on a written letter to consumers from the bank, notifying them of the redress including the relevant requirements on the envelope containing the letter. ${ }^{121}$

To help inform consumers, the CFPB also published a blog post for Capital One customers explaining the announcement and the refund process. The statement on CFPB's blog emphasized the convenient repayment process: ${ }^{122}$

Convenient repayment for consumers: If the consumers are still Capital One customers, they will receive a credit to their accounts. If they are no longer a Capital One credit card holder, they will receive a check in the mail. Consumers are not required to take any action to receive their credit or check. ${ }^{123}$

The CFPB also posted a general blog post to all consumers informing them how to "Stop Mystery Credit Card Fees" from their card issuers. ${ }^{124}$

\footnotetext{
consumerfinance.gov/about-us/newsroom/cfpb-orders-citibank-to-pay-700-million-inconsumer-relief-for-illegal-credit-card-practices/ [https://perma.cc/ZNA2-336C].

115. Consumer Financial Protection BuReau, supra note 95.

116. Bank of America Consent Order, supra note 90, at 26.

117. Capital One Bank Consent Order, supra note 01, at 14.

118. Consumer Financial Protection Bureau, supra note 103.

119. Id.

120. Capital One Bank Consent Order, supra note 90 at 15-17.

121. Id. at 17.

122. Kent Markus, How will the Capital One order handle refunds? Consumer Financial Protection BUREAU (July 18, 2012), https://www.consumerfinance.gov/about-us/blog/capitalone-order-refunds/ [https://perma.cc/CSK2-6RFD].

123. Id.

124. Gail Hillebrand, How to stop mystery credit card fees, CONSUMER FINANCIAL Protection Bureau, (July 18, 2012), https://www.consumerfinance.gov/about-us/blog/stopmystery-credit-card-fees/ [https://perma.cc/8DY8-X99J ].
} 


\section{(3) Implications}

The CFPB consent order-type of consumer redress scheme is unique in that it does not require consumers to file a complaint or take any action, but instead "automatically" repays them with credit or a check. The CFPB consistently uses this method of redress in all of its consent orders related to credit card add-on products. Although this automatic repayment method is immensely convenient and favorable to the consumer, it does raise the concern that the CFPB might be inappropriately imposing a blanket restitution plan for instances of deception or mis-selling that usually require individual review to determine the extent of the bank's culpability toward each customer. One possible reason why such a broad-based plan makes sense is that consent orders, which are a type of settlement between a private party and an administrative agency, ${ }^{125}$ were the legal instrument that the CFPB employed, and there is a degree of flexibility allowed for this. ${ }^{126}$ Another possibility is that in many cases, the sales representatives used a common sales script, which created a pattern of behavior that the CFPB could apply to a range of cases. In those instances, the CFPB and the regulated entities could issue a blanket, automatic refund to eligible customers. Finally, it is also possible that the redress amounts for these types of credit card add-on products were typically low, while individual screenings of each deception or mis-selling would be more costly than a blanket refund to all consumers in a particular sale.

Once a firm has entered into a consent order with the CFPB, it must abide by the terms of the Bureau's order and is subject to the Bureau's oversight regarding implementation of the order. As such, we can characterize the CFPB consent order as a "hard" enforcement, where a public authority mandates a consumer redress scheme. ${ }^{127}$

\section{South Korea}

In South Korea there was a widespread mis-selling scandal in which credit card companies mis-sold Debt Cancellation and Debt Suspension (DCDS) products to millions of consumers. ${ }^{128}$ The Financial Services Service (FSS),

125. Stefanie H. Jackman \&Daniel L. Delnero, CFPB's Systemic Regulation of Four Industries: Enforcing Broader Changes Via Consent Order, 31 LEgAL BACKGROUNDER 16, 1 (2016).

126. See August Horvath, John Villafranco, \& Stephen Calkins, ABA SECTION OF ANTITRUST LAW CONSUMER PROTECTION LAW DEVELOPMENTS 259 (2009) (similarly, courts have afforded the FTC a wide discretion for cease and desist orders in enforcing deceptive and unfair practices).

127. In theory, since the financial companies can voluntarily choose to (or decline to) enter a consent order, the CFPB's consent order-type of regulatory redress can also be understood as a voluntary regulatory redress.

128. This section was largely adapted from an article that the author wrote in Korean. You Kyung Huh, Consumer Friendly Consumer Redress - A Comparative Case Study on Consumer Redress in Large Scale Mis-selling Scandals-, [소비자친화적인 금융소비자 피해구제 대규모 
Korea's primary financial regulatory agency, stepped in and compelled the relevant financial companies to provide redress to the defrauded consumers.

\section{(1) Misconduct Related to DCDS Products Sale}

DCDS products, which Samsung Card first introduced in 2005, are a type of insurance service that credit card companies offer customers. The products come with fees that the companies add to the monthly bills. The fees vary depending on the total monthly card usage and the rates fixed by card companies. The service allows customers to cancel or suspend payments in the event of death or illness.

As of the end of 2016, 2.7 million customers had signed up for this product. The related average monthly charge was about 6 USD $(6574 \mathrm{KRW}) .{ }^{129}$ Between 2012 to 2016 the product created a total revenue of more than 10 billion USD (1.18 trillion KRW). ${ }^{130}$

DCDS products were usually mis-sold sold by way of various aggressive telemarketing techniques. For example, company representatives often failed to get the consumer's explicit consent; sometimes they did not mention that products came with a fee for the service (i.e., they promoted the product as a VIP customer service, confusing consumers into thinking that the products were free, when in fact fees were charged). ${ }^{131}$ Sometimes the telemarketer spoke so quickly that it was impossible for the consumer to comprehend the complicated terms. ${ }^{132}$

The most common type of consumer misunderstanding was about the way that the company assessed the fees for DCDS. It did so with the formula of multiplying a multiplier (i.e., $0.5 \%$ ) to the remaining credit card balance at the end of the month. ${ }^{133}$ Often, the product marketing promised that "the fee would usually be less than a dollar or less than ten dollars." ${ }^{134}$ Some consumers misunderstood that the fee would be a flat fee, when in fact it fluctuated commensurate to the amount of the month-end balance. At times, the scope and

불완전판매에 대한 소비자 피해구제 사례 연구를 중심으로] S. KoR. Bus. L. Assoc., 32 Bus. L. REv. 317, 319-24 (2018).

129. Id. at 321 (citing the Board of Audit of Korea Board of Audit and Inspection, Notice, Improper Guidance and Supervision of Credit Card Companies' Ancillary Work) [감사원, 통보, 신용카드사 부수업무 수행에 대한 지도·감독 부적정]) .

130. $I d$.

131. Id.

132. Id. (citing Korea Conusmer Agency, Research Report, Problems and Reform Proposals for Credit Card Add-on Products [Debt Cancellation and Debt Suspension] (2015) [한국소비자원, 조사보고서: 신용카드사 부가상품 [채무면제·유예상품] 문제점 및 개선방안]).

133. Id.

134. Id. 
meaning of balance was unclear to the consumer. In most cases this term included not only credit card balances but also the sum of other credit services that the credit card company offered (i.e., short-term loans, installment loans and revolving credit) which typically came to much more than just the monthly credit card bill. ${ }^{135}$ In other words, depending on the type of contract, the company often carried over the total amount of the installment or the revolving amount from the previous month, including it in the next month's balance for the purpose of calculating DCDS fees. If a customer had a significant balance, then the fees could run up to tens or hundreds of dollars, considerably more than the amount that telemarketers had promoted.

As a result of this kind of fraudulent sale, DCDS-related complaints filed with the Korea Consumers Agency (KCA) and the FSS increased significantly after 2010. In 2015-2016, DCDS-related complaints ranked at the top of all credit card-related complaints, and mis-selling was the most common factor $(78.6 \%)$ of all such DCDS-related complaints. ${ }^{136}$

\section{(2) Regulator's Response and Consumer Redress}

The increase of DCDS consumer complaints after 2010 triggered the FSS to issue a series of regulatory actions relating to DCDS products. In 2013, the FSS required the credit card companies to lower DCDS fees. ${ }^{137}$ In 2015, the FSS prepared a comprehensive review of the business conduct of all credit card companies. ${ }^{138}$ In May 2016, the FSS entered into a Memorandum of Understanding (MOU) with the credit card companies seeking to improve business conduct. ${ }^{139}$ From November to December 2016, the FSS reviewed the credit card companies' performance of the MOUs. In this process the FSS found the credit card companies had mis-sold the DCDS and advised the companies to repay the mis-sold funds to the consumers. ${ }^{140}$ The FSS determined that 650 thousand customers were eligible for reimbursements amounts of 23 million USD (KRW 26.1 trillion). ${ }^{141}$ As the problem persisted, in 2016 the authorities banned new sales of DCDS products altogether (although customers who already bought DCDS products remained subscribed unless they cancelled their

135. Id.

136. Id. at 322 .

137. Eun-Joo Lee, Card companies cut DCDS charges, KoREA JoONGANG DAILY (Apr. 18, 2013), http://koreajoongangdaily.joins.com/news/article/article.aspx?aid=2970323 [https:// perma.cc/2RV9-AT4X].

138. You Kyung Huh, supra note 128, at 322 (citing Financial Supervisory Service, Press Release, Title: Results and Future Plans for Reforming the Improper business practices of Credit Card Companies (Feb. 9, 2017)).

139. Id.

140. Id.

141. Id. 
subscriptions). ${ }^{142}$

The credit card companies' consumer redress procedures were not uniform. In some cases, the companies automatically repaid amounts even though the consumers had not filed a complaint. The companies themselves identified and reached out to this group of customers in order to make restitution. But in other instances, the companies made redress payments only if the consumers individually filed complaints with them. When consumers did this, the credit card company would listen to the recording of the sale, and if it deemed it a misselling, then the consumers were eligible for a repayment.

Many consumers were not aware of widespread mis-selling and of their eligibility to redress; in fact, many did not even realize that they had subscribed to DCDS services. As such, the FSS required the credit card companies to notify DCDS customers in writing, at least once a year, (i) of the fact that the customer had enrolled in DCDS services, (ii) of the monthly fees for the product, (iii) of the scope of the services, and (iv) of the fact that consumers were eligible to cancel the services if they deemed them unnecessary. ${ }^{143}$ The companies also had to notify DCDS consumers of the past three months' worth of fees for the product through text messages. The FSS required the credit card companies to operate call centers with numbers dedicated for DCDS products so that consumers could confirm their DCDS subscription status and cancel the service if they so chose. The local media and social network services (internet portals, etc.) also published information about the DCDS mis-selling scandal. This helped many consumers become aware of the product, allowing them to file complaints with their credit card companies.

In September 2017, however, the Board of Audit and Inspection (BAI) of Korea, ${ }^{144}$ a national audit agency, published a report that found the FSS' handling of the DCDS mis-selling scandal deficient. ${ }^{145}$ According to the report, the scope of DCDS subscribers who were eligible for redress was much broader than that which the FSS had initially identified. The BAI found that the FSS had wrongly excluded more than 2.2 million consumers from its initial consumer redress scheme. ${ }^{146}$ The BAI noted the likelihood that these consumers were not aware of mis-selling and that the FSS had been wrong in not devising a way to

142. Kyung-min Lee, Regulator inspects card firms ahead of fee reduction, THE KOREA Times (Aug. 7, 2019), http://m.koreatimes.co.kr/pages/article.asp?newsIdx=258702 [https://perma.cc/6EAU-GBJT]

143. You Kyung Huh, supra note 128, at 322-23.

144. The Korean constitution created the BAI as a public agency with the primary function of the auditing and inspecting the accounts and the work of government agencies. Responsibilities \& Functions, Board of Audit and Inspection, BAI (http://english.bai.go.kr/bai_eng/html/about/responsibilities.do?mdex=bai_eng8) [https://perma. cc/DWH5-8YJ5] (last visited Aug. 5, 2019).

145. You Kyung Huh, supra note 128, at 323 (citing the Board of Audit of Korea Board of Audit and Inspection, Notice, Improper Guidance and Supervision of Credit Card Companies' Ancillary Work) [감사원, 통보, 신용카드사 부수업무 수행에 대한 지도·감독 부적정]).

146. $I d$. 
protect them as well.

As of this date, there is no evidence that the FSS has publicly orchestrated another, broader mis-selling consumer redress scheme for the DCDS products. The Korea Consumer Agency's consumer call centers continued to receive complaints about DCDS mis-selling as late as 2018, so it appears that there is still a large number of consumers who might be eligible for redress. As of 2018 March, 2.1 million customers still received DCDS services. ${ }^{147}$

The BAI audit results and the existence of consumer complaints as late as 2018 show the importance of properly informing eligible consumers in a consumer redress scheme. We have seen above that the FSS publicized its redress scheme through media exposure, occasional discussions in SNS posts, and direct notification from the credit card companies. Nevertheless, these attempts were not sufficient to reach all (potentially) mis-sold consumers and to encourage them to seek redress.

\section{(3) Implications}

The FSS intervened in the problematic sector at an early stage by using both its formal and its informal supervisory powers. It is important to note that the FSS "advised" the credit card companies to offer redress, but could not legally "require" them to do so. Korean legal academics categorize these types of "advisories" as a type of "administrative guidance (Haengjungjido),"148 which has no binding legal effects on the parties that receive them. These so-called advisories, however, have a de facto power which can compel financial companies to abide by them. ${ }^{149}$ Because administrative guidance is not legally binding, the agency needs no specific legal ground to issue one and can use them informally and flexibly in a wide variety of situations.

Indeed, there is no legal ground for consumer redress under Korean law. The FSS can only "advise," or recommend, redress through informal administrative advisories and agreements (taking the form of MOUs) between the regulator and the financial companies.

147. Id. DCDS statistics available at the Credit Finance Association of Korea website, 채무면제·유예상품, 여신금융협회 공시정보포털,

https://gongsi.crefia.or.kr/portal/creditcard/creditcardDisclosureDetail22?cgcMode=22\#! [https://perma.cc/H7EN-NERP]) (in the Korean language).

148. Article 2 (3) of the Korean Administrative Procedure Act stipulates that "The term "administrative guidance" [(Haengjungjido), ] "means an administrative action, such as guidance, recommendation, advice by an administrative agency to encourage or discourage a particular person regarding performance of certain acts, within the scope of duties or affairs under its jurisdiction in order to realize specific administrative aims..." Korean Administrative Procedure Act, Act No. 12347, Jan. 28, 2014, art. 2(3) (S. Kor.).

149. In part, this is because financial authorities have a wide variety of enforcement tools that can be implemented to encourage a voluntary redress scheme. See infra section IV. Another reason can be attributed to the Korean of tradition of a strong state led economy where authorities have a strong influence over the industry beyond the black letter of the law. 
The informal 'advisory' method has both advantages and disadvantages. On the one hand, the regulators can be flexible in designing redress schemes that are not available in the letter of the law. On the other hand, precisely because there are no clear legal guidelines regarding consumer redress, it is up to the good will of the financial companies to design and manage a robust restitution scheme. The DCDS redress scheme above showcases both - the FSS could flexibly intervene at a relatively early stage and "advise" the credit card companies to offer redress, but as the BAI chided, the FSS was also hesitant in using its informal powers and so did not intervene as forcefully as it might have, had it the formal authority to do so. When the credit card companies chose not to operate a robust redress arrangement, the FSS did not have the power to follow up on the advisory by, say, imposing administrative fines, sanctions, or penalties. This leaves consumers who are not aware of their rights in an undesirable limbo status.

\section{WHY REGULATORY MASS REDRESS WORKS WELL FOR THE FINANCIAL SECTOR}

The case studies above all present the mis-selling of similar financial products. Although the three relevant nations operated redress schemes against the framework of very different legal and cultural backgrounds, the results of delivering mass redress to millions of low-value claims were identical. ${ }^{150}$

Why is the financial sector an area to which regulatory redress schemes are so appropriate? Would it be preferable for this area to develop mass regulatory schemes? In short, would it be more effective for countries to adopt a formal regulatory redress scheme or for them to activate informal redress schemes, especially in the financial sector? This section will examine these questions.

First, more than most other industries, the financial services sector is heavily regulated. This creates unique opportunities for regulators to access information and intervene at an early stage. Financial companies are under constant on-site and off-site supervision through bank examinations and various reporting and approval requirements. In their supervisory role, financial regulators can also have informal interactions (such as meetings, calls, and emails) with regulated entities. The benefit of the constant supervisory function of a financial regulator is that it can detect problems and intervene at an early stage. Access to a wealth of information through the supervisory function also remedies the difficulties in gathering information that are often present in an in-court consumer redress case. The discovery procedure in certain jurisdictions (i.e., the U.S.) alleviates this problem, but in some nations (i.e., South Korea), practitioners find it hard to come up with evidence in instances of financial harm. Regulatory redress, instigated or ordered by a financial regulator, answers this problem.

150. See supra, Section II.B. Waye \& Morabito supra, note 3. Other nations, like Italy and Australia, have also instituted formal mass regulatory redress schemes. 
Second, financial regulators are armed with a variety of enforcement tools to invoke or supplement consumer redress, and these enhance the effectiveness of a redress scheme. In addition to the supervisory process, regulators have their own investigatory powers to help them reach an enforcement decision. Regulators have an array of tools for enforcing laws, including criminal and administrative penalties, and powers such as cease and desist orders and injunctions against infringement. These actions alone might have deterrence effects, but they cannot redress consumer harm, and so are not helpful to defrauded customers. The value of this array of enforcement tools lies in the fact that they can induce or influence a regulated entity to implement a swifter and more robust redress plan. ${ }^{151}$ In nations where authorities do not have mandatory redress powers, regulators can derive a de facto power to encourage a voluntary redress from de jure enforcement powers. In other words, regulatory redress is effective because it can be used in tandem with other enforcement tools. ${ }^{152}$

Third, the consumer harm that financial products cause can easily be widespread, inconspicuous, and of little value on an individual level. The case studies on mis-sold PPI and credit card add-on products illustrate this point. Unlike defective manufactured goods, the consumer harm that financial services contracts generate can go unnoticed for months or even years. In the U.K., PPI consumers were unaware of the scandal for decades. Consumers easily overlooked financial charges on their monthly bills (especially in low amounts), even when companies added them illegally. Other examples of low-value but widespread harm in the financial sector abound. For example, in Ireland, about 160,000 people were eligible to claim between $€ 100$ and $€ 200$ each for having been mis-sold a credit card protection policy. ${ }^{153}$ In Latvia, it took more than two years for anyone to notice that a large consumer credit company was misleading consumers with respect to interest rates on credit cards. ${ }^{154}$ Regulatory consumer redress, especially "automatic" redress schemes where financial companies pay refunds even to consumers who have not filed a consumer complaint is particularly useful for these types of small amount cases. ${ }^{155}$

Finally, it is foreseeable that digitalization in the financial sector will create more possibilities for inconspicuous, widespread harm. The rapid evolution of technology in the financial area has fundamentally changed the way that companies sell these services, while diminishing consumers' ability to understand the financial transactions. This increased consumer vulnerability will inevitably lead to an increase in unfair and deceptive trade practices,

151. HodGes \& VoET, supra note 1, at 154.

152. Hodges supra, note 13, at 19, 20.

153. Collective Redress for All Europeans, BEUC: THE European CONSUMER ORGANISATION, https://www.beuc.eu/collective-redress-all-eu-consumers\#examples [https:// perma.cc/A8ZS-SQQE ] (last visited Aug. 6, 2019). However, Ireland does not have a collective redress system to facilitate this restitution.

154. Id.

155. The case study on the CFPB refunding consumers is a good example of this. 
including fraud and mis-selling, as well as account hacking and data theft. ${ }^{156}$

\section{DESIGNING AN OPTIMAL REGULATORY REDRESS SCHEME}

\section{A. Balancing Benchmarks}

The three case studies show that regulatory redress schemes operate in the broader milieu of each nation's unique civil justice system and financial regulatory architecture. The customs and traditions, the cultural factors, and the nature of existing relationships between authorities and regulated entities also contribute to the various approaches. Despite these differences, however, we can derive common benchmarks that legislators should consider when designing an effective regulatory redress scheme.

First, a regulatory reparations scheme that is set against judicial redress can be efficient, even though it raises concerns about the right to fair trial and due process. Judicial redress is tedious and resource-intensive but it demonstrates the most reverence to the rule of law. The right to a fair trial, with an independent judiciary that considers the evidence and applies the law, gives way in a regulatory redress scheme to efficiency and expediency. Some types of regulatory redress schemes replace due process with the voluntary consent of the regulated. ${ }^{157}$ For example, the use of consent orders in the US CFPB case study bypasses any procedural requirements for adjudication and allows the administrative agency and the parties involved to resolve an agency-initiated proceeding without the time and expense of a formal administrative hearing. ${ }^{158}$ In the Korean FSS case study, we saw that there was no legal framework for imposing the redress scheme; there, the authorities' informal advice and recommendation replaced the rule of law. However, in this situation, where regulatory redress procedures lack the minimum procedural guarantees of a court-led redress or a formal enforcement action, such a scheme might infringe on the consumer's right to a fair trial or to due process for the participating parties. ${ }^{159}$

156. G20/OECD Policy Guidance: Financial Consumer Protection Approaches in the Digital Age, OECD 13, 14 (2018), http://www.oecd.org/g20/G20-OECD-Policy-GuidanceFinancial-Consumer-Protection-Approaches-digital-age.pdf [https://perma.cc/XNL6-YZHS].

157. Micheal Legg, Many wrongs can make a right: how mass redress schemes can replace court action, THE CONVERSATION (Nov. 24, 2015), http://theconversation.com/many-wrongscan-make-a-right-how-mass-redress-schemes-can-replace-court-action-51118) [https://perma.cc/9RCL-4E8J].

158. 12 C.F.R. $\$ 1081.120$ (c)(3)(v) (2012). By submitting an offer of settlement, the person making the offer waives, subject to acceptance of the offer, judicial review by any court.

159. For example, Article 6 of the European Convention on Human Rights notes the following: "In the determination of his civil rights and obligations or of any criminal charge against him, everyone is entitled to a fair and public hearing within a reasonable time by an independent and impartial tribunal established by law.” Y.B. Eur. Conv. on H.R. 
Second, procedural rules for court-led remedies usually have safeguards to ensure openness and transparency, characteristics that some regulatory redress schemes lack. The schemes can set aside hearings, the publication of the content and documents of files, transcripts of statements, and rules on ex parte communication. More "formal" regulatory redress schemes can have more procedural mechanisms to enhance transparency. For example, the FSA/FCA formalized the U.K. PPI redress scheme through Policy Statements, revisions of relevant sections of the Handbook, and written guidance. That the U.K. financial regulators published consultation papers seeking feedback from the industry, consumers, and other stakeholders before they set forth new rules shows a high degree of transparency and openness regarding the rules and procedures that they applied to the PPI redress scheme. Critics of the CFPB's frequent use of consent orders argue that it used these orders as a way to evade formal rulemaking, something that the CFPA allowed it to do. ${ }^{160}$ In this way, however, the critics argue, the CFPB deprived companies of fair notice of prohibited conduct ${ }^{161}$ This claim brings to the fore the necessity that procedures for regulatory redress schemes be transparent, so that participating parties and interested stakeholders can assess the fairness of the redress.

\section{B. Design Factors}

With the basic benchmarks of efficiency, fairness, due process, transparency, and openness in mind, we now turn to the policy decisions involved in designing a specific regulatory redress scheme.

\section{a. Ceiling Amount or Threshold Issues}

First, we need to identify the extent of the need for mass redress and whether there should be a ceiling amount of compensation that can be awarded via regulatory redress schemes. Regulatory mass redress schemes are most effective for low-value claims because consumers are less likely to seek redress for them in court (while there is an increased chance that they will do so for high-value claims). The higher the stakes in individual cases, the greater the necessity for a fair trial, judicial consideration of the evidence, and the application and interpretation of the law. Voluntary redress or "soft" regulatory redress (such as administrative advice or inducement) becomes less likely in high-value cases where regulated entities are unlikely to settle. ${ }^{162}$

160. See 12 U.S.C. $\$ 5531(b)$ (2010). McDonald, supra note 91.

161. Jackman \& Delnero, supra note 125.

162. See Park-Eun Jee, Samsung Life defies FSS, sues policyholder, KoREA JoONGang DAILY (Aug. 14, 2018), http://koreajoongangdaily.joins.com/news/article/article.aspx?aid= 3051875 [https://perma.cc/V3JR-RXKT]. In this case the FSS attempted to impose a voluntary redress scheme, but the redress amount per consumer that it determined was ten times more than the amount that regulated entity believed appropriate. The large amount at stake and the 


\section{b. The Right to Appeal and Court Participation}

Another policy option is to determine the degree to which the regulated entity should be allowed to appeal or whether a court action is required to complete the redress. By definition, in a voluntary redress scheme (i.e., a consent order) the regulated entity agrees to forgo judicial review. However, a mandatory framework, where a public authority can coerce a redress scheme, raises constitutional issues of the right to appeal and the right to be heard. ${ }^{163} \mathrm{~A}$ middle ground arrangement could be a model where administrative authorities can bring a case to court to seek collective redress (here it is the regulators who initiate the regulatory actions for redress), but where the court ultimately determines the extent or format of any redress. ${ }^{164}$

\section{c. How to Reach Out to Consumers}

A recurring theme in collective action is to how to determine the class; that is, should it be an opt-in, where a class member needs to take affirmative action to be included in the group, or an opt-out, where a customer need do nothing at all in order to part of the final outcome. A similar policy choice in regulatory redress schemes is to determine whether consumers must file a complaint or take action to receive restitution (as in the U.K. PPI redress case) or whether the redress is "automatic," so that consumers automatically receive payments through their bank accounts or mailed checks (as in the U.S. CFPB consent order). If the scheme requires consumers to take action in order to receive refunds, authorities must implement sufficient measures to ensure that the members of the relevant "class" are aware of the possibility of harm. ${ }^{165}$ Thus, there is a necessary policy choice between the "automatic" payment method (consumers need not take action for redress) and the "opt-in" payment method (in which consumers must file a complaint with the firm or relevant authorities in order to receive payment).

\section{d. The Degree of Autonomy or Self-regulation of the Regulated Entity}

A final policy decision concerns the degree of the financial companies' discretion in administering regulatory redress schemes. Even when authorities

differences in legal interpretation of the terms and conditions of the insurance contract contributed to the lawsuit.

163. See Hodges, supra note 13, at 18.

164. See supra Section II.B.

165. The U.K.'s PPI case shows that the FCA took great care to publicize the PPI's mass harm. The Korean DCDS case demonstrates the pitfalls of regulatory redress when members of a potential "class" are not properly notified. The U.S. CFPB case shows how simple an automatic redress can be from the consumer's perspective. 
order mandatory repayment, they might still be flexible in the way that the firm manages the redress scheme and handles individual claims. In other cases, the authorities themselves might determine the specific formula that calculates the repayment amounts. Generally speaking, more regulation (less discretion) creates a fairer and more level field among consumers and firms, while allowing self-regulation and a higher degree of autonomy can enhance market efficiency, as firms can find a specific solution that best fits their case. ${ }^{166}$

\section{CONCLUSION}

Several countries have successfully deployed regulatory mass redress schemes, proving that these can be potent alternatives to slow and inefficient court-led collective actions. For mass harm, regulatory mass redress is a great improvement over the conventional individual form of ADR or ODR. Thus, regulatory redress schemes, often used in tandem with consumer ombudsmen systems, are rightfully called the newest redress "technology" 167 and deserve more attention from policymakers and academia.

The case studies show wide variations among the regulatory redress schemes that different nations use, which has made it difficult for policymakers to identify this technique as a distinct solution for mass harm. The discrepancies have also made it difficult for them to pinpoint commonalities among the plans and categorize the necessary policy decisions. This article clarifies the issue by presenting some of the relevant considerations - the efficiency gains, the right to a fair trial, due process concerns, and the degree of openness and transparency. Based on these points, policymakers must make specific design choices such as determining a threshold necessary to activate a redress scheme, or the prescribed maximum amount of repayment that a regulatory redress scheme will offer. Determining the extent of the court's contribution, including a party's right to appeal a regulatory redress order, is also an important policy choice. As a more practical matter, figuring out how to reach harmed consumers and repay them is yet another direction in which nations have greatly diverged. Finally, legislators must establish the degree of autonomy that they will allow the firms in managing their redress schemes.

There are no correct answers to any of the policy choices. Among other factors, the extent of the harm and the expected amount of redress for a typical case are relevant and will vary from case to case. In addition, a nation's tendency to allow industries to self-regulate or its deference to regulatory authority are also important considerations when determining the rigidity of a regulatory

166. See Pablo Cortes, Accredited online dispute resolution services: creating European legal standards for ensuring fair and effective processes, 17 INFO. \& СомM. TECH. L. 221, 223-24 (2008).

167. See generally HoDGES \& VOET, supra note 1. 
redress scheme.

What is clear is that regulatory mass redress - not court litigation and not redress of individual cases - is the most efficient way to deal with certain types of mass harm that occur frequently in certain industries. The case studies in this paper illustrate that the financial sector is an area in which mass harm occurs commonly and that regulatory mass redress has been an effective way to tackle it.

Given that the concept of regulatory mass redress is a relatively novel way to compensate harmed consumers, I hope that this paper will stimulate research on the regulatory mass redress cases of other nations and lead to additional discussion about the policy choices involved in designing optimal redress schemes, as well as to the further development of new techniques for consumer redress. 